\title{
RELAY RACES ALONG A PAIR OF SELECTABLE ROUTES
}

\author{
E.V. Larkin ${ }^{1}$, A.V. Bogomolov ${ }^{2}$, A.N. Privalov ${ }^{3}$, N.N. Dobrovolsky ${ }^{1}$ \\ ${ }^{1}$ Tula State University, Tula, Russian Federation \\ ${ }^{2}$ Burnasyan Federal Medical Biophysical Center of Federal Medical Biological Agency, \\ Moscow, Russian Federation \\ ${ }^{3}$ Tula State Lev Tolstoy Pedagogical University, Tula, Russian Federation \\ E-mail: elarkin@mail.ru, a.v.bogomolov@gmail.ru,privalov.61@mail.ru, \\ nikolai.dobrovolsky@gmail.com
}

\begin{abstract}
Case of two teams competition, which should overcome the distance divided onto stages, is considered. In the case under consideration, every stage has its own number of routes, which the participants of the team may select to overcome. It is shown, that competition bears the character of the relay race, and two-parallel semi-Markov process is the natural approach to modelling of the situation.

From all possible routes two were selected. The conception of switching space, which display all possible switching trajectories is proposed. The formula for calculation of switching trajectories number is acquired. It is shown, that ordinary semi-Markov process with the use of the recursive procedure may be obtained from the complex two-parallel semi-Markov process, which describes the wandering through selected routes. The formulae for realization of the recursion are proposed.

Conception of distributed forfeit is proposed. It is shown, that forfeit depends on difference of stages, teams overcome at current time, and routes, on which participants solved to overcome stage. The formula for estimation of total forfeit, which one team pays to other team is obtained. It is shown, that the sum of forfeit may be used as the optimization criterion in the game strategy optimization task.
\end{abstract}

Keywords: relay race; two-parallel semi-Markov process; distance; stage; route; distributed forfeit; recursive procedure.

\section{Introduction}

The paired relay race is the basic principle of any concurrency unfolding in physical time in manifold fields of a human activity, such as economics, politics, defense, sport, etc. [1-4]. Classic relay races presume that a distance, teams should overcome, is divided onto stages [5], and stages with the same numbers are equal to both teams of the participants. If the distance overcoming efficiency depends on the winning or losing the stages, than there is only one way to win the race as a whole: to win all the stages of the distance. This solution is acceptable for a team, which has necessary resources to maintain a selected high speed on the stage, but if it has not, team tries to find asymmetric response, which supposes reaching the final point of the distance along the alternative route, which the participants can select. In this case there is a number of parameters, the teams can vary and control, namely, division the distance on the stages, time characteristics of overcoming stages, routes of the stages.

For an external observer selection of routes by the participants of the team is made randomly, so model of running the distance on selected routes should be the stochastic one $[6,7]$. The availability of alternative generates premises for the emergence of game situations. Those teams which can evaluate the benefits and losses from choice of this or 
that distance route, may construct the optimal strategy of relay races games for winning the competition as a whole.

Approaches for forecasting of benefits and losses of relay-races games are currently known insufficiently, that explains necessity and relevance of the investigations in this domain.

\section{The Structure and the Model of Paired Alternative Route Relay-Race}

Distance, stages and routes are shown in Fig. 1, which explain the following assumptions [5]:

1) relay race includes two teams of participants, $A$ and $B$;

2) teams act independently of each other and should overcome the distance in a real physical time;

3) the distance is divided into $J$ stages;

4) $j$-th stage of $A$ team includes $K(A, j)$ routs, $j$-th stage of $B$ team includes $K(B, j)$ routes $K(A, j) \neq K(B, j)$;

5 ) after finishing $j$-th stage the participant of team $A$ may choose one of $K(A, j+1)$ possible routes of the $(j+1)$-th stage, after finishing $j$-th stage the participant of team $B$ may choose one of $K(B, j+1)$ possible routes of the $(j+1)$-th stage;

6 ) both teams, $A$ and $B$, start the distance at once;

7) the time of passing of $k(A, j)$-th route, $1(A, j) \leq k(A, j) \leq K(A, j)$ by the participant of team $A$ is a random one, and is defined with accuracy to density;

8) the time of passing of $k(B, j)$-th route, $1(B, j) \leq k(B, j) \leq K(B, j)$ by the participant of team $A$ is a random one, and is defined with accuracy to density;

9 ) after completion of $j$-th stage by previous participant next participant starts $(j+1)$ th stage without a lag;

10) winning or losing of the competition stage is understood as completion of the stage the first or not the first;

11) winner's forfeit is distributed in time and depends on the difference of stages and routes, which a winner and loser pass.

In addition to assumptions:

1) nodes $\left\{{ }^{A} a_{0}, \ldots,{ }^{A} a_{j}, \ldots,{ }^{A} a_{J}\right\}$ of graph "Team A" mean relay points of distance, which should overcome team $A$;

2) nodes $\left\{{ }^{B} a_{0}, \ldots,{ }^{B} a_{j}, \ldots,{ }^{B} a_{J}\right\}$ of graph "Team B" mean relay points of distance, which should overcome team $B$;

3) nodes ${ }^{A} a_{0}$ and ${ }^{B} a_{0}$ are the starting points of the distance;

4) nodes ${ }^{A} a_{J}$ and ${ }^{B} a_{J}$ are the end points of the distance.

The model of the paired alternative route relay-race may be performed as two-parallel semi-Markov process [7-9]

$$
h(t)=\left[\begin{array}{cc}
{ }^{A} h(t) & 0 \\
0 & { }^{B} h(t)
\end{array}\right],
$$

where $t$ is the time, ${ }^{A} h(t),{ }^{B} h(t)$ are semi-Markov matrices [8, 10,11] of size $J \times J, \boldsymbol{O}$ is the zero matrix of size $J \times J$ and

$$
{ }^{A} h(t)=\left[h_{m(A), n(A)}(t)\right], \quad{ }^{B} h(t)=\left[h_{m(B), n(B)}(t)\right] .
$$




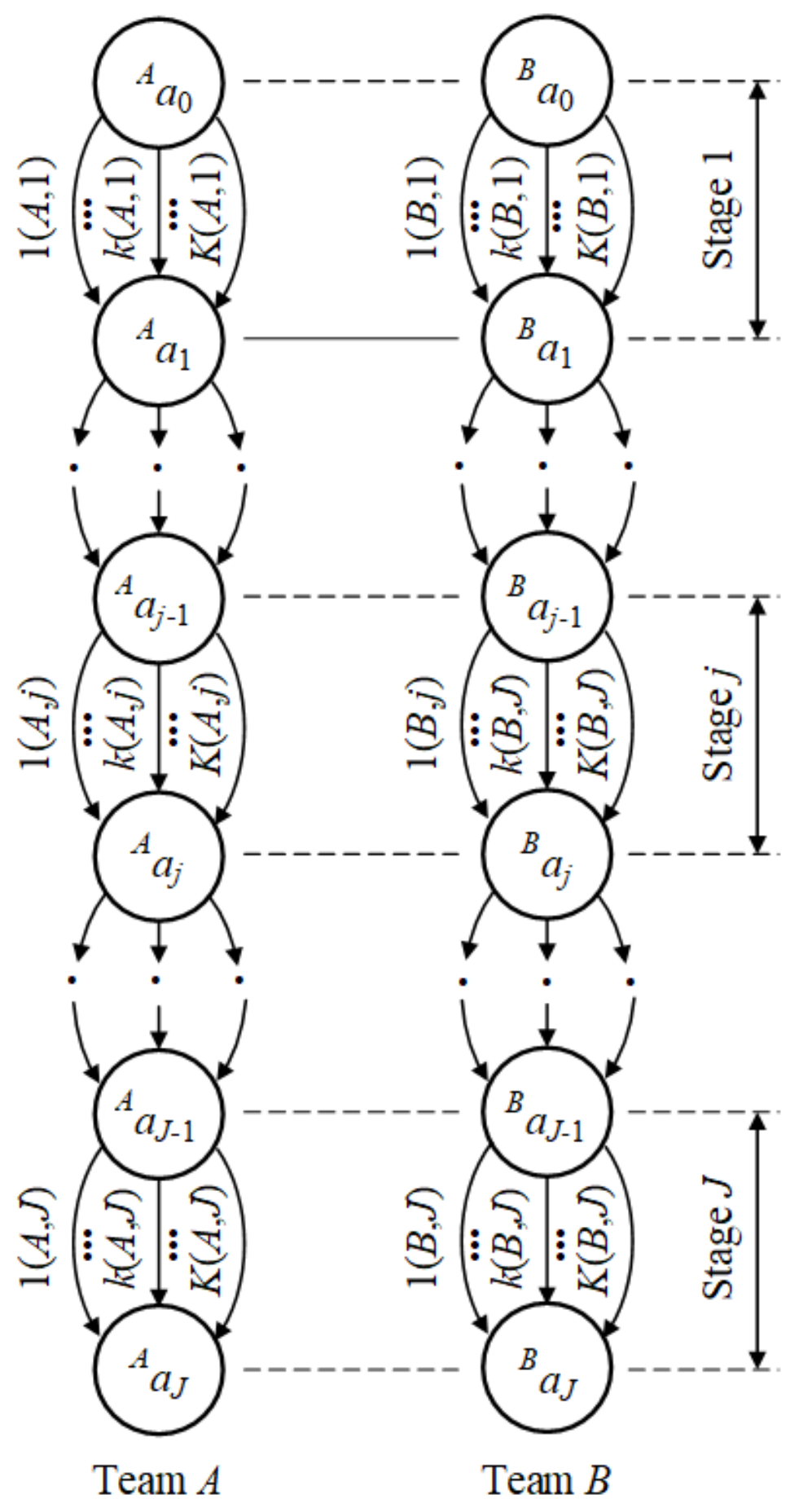

Fig. 1. Relay-races with alternative routes

In its turn semi-Markov matrices (2) are as follows

$$
{ }^{A} h(t)=\left[{ }^{A} h_{j, l}(t)\right], \quad{ }^{B} h(t)=\left[{ }^{B} h_{j, l}(t)\right],
$$

where ${ }^{A} h_{j, l}(t),{ }^{B} h_{j, l}(t)$ are elements of matrices (3), correspondingly, disposed on the 
intersection of $j$-th row and $l$-th column

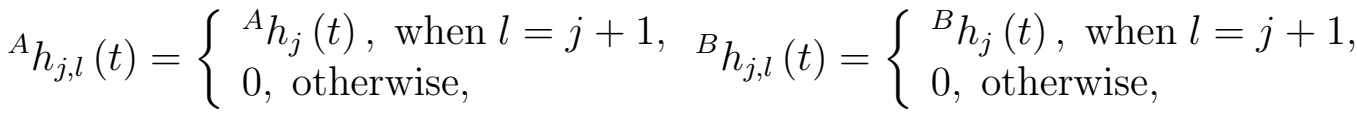

$$
\begin{aligned}
& { }^{A} h_{j}(t)=\left[h_{1(A, j)}(t), \ldots, h_{k(A, j)}(t), \ldots, h_{K(A, j)}(t)\right], 1 \leq j \leq J, \\
& { }^{B} h_{j}(t)=\left[h_{1(B, j)}(t), \ldots, h_{k(B, j)}(t), \ldots, h_{K(B, j)}(t)\right], 1 \leq j \leq J, \\
& h_{k(A, j)}(t)=p_{k(A, j)}(t) f_{k(A, j)}(t), \\
& h_{k(B, j)}(t)=p_{k(B, j)}(t) f_{k(B, j)}(t) \text {, } \\
& p_{k(A, j)}=\int_{0}^{\infty} h_{k(A, j)}(t) d t ; p_{k(B, j)}=\int_{0}^{\infty} h_{k(B, j)}(t) d t,
\end{aligned}
$$

where $p_{k(A, j)}$ is the probability of choice of $k(A, j)$-th route by $j$-th participant of team $A, p_{k(B, j)}$ is the probability of choice of $k(B, j)$-th route by $j$-th participant of team $B$, $f_{k(A, j)}(t)$ is the time density of overcoming $k(A, j)$-th route by $j$-th participant of team $A$, $f_{k(B, j)}(t)$ is the time density of overcoming $k(B, j)$-th route by $j$-th participant of team $B$, $h_{k(A, j)}(t)$ is the weighted time density of overcoming $k(A, j)$-th route by $j$-th participant of team $A, h_{k(B, j)}(t)$ is the weighted time density of overcoming $k(B, j)$-th route by $j$-th participant of team $B$.

For ${ }^{A} h_{j}(t),{ }^{B} h_{j}(t)$

$$
\sum_{l(A, j)=1}^{K(A, j)} p_{k(A, j), l(A, j)}=1, \quad \sum_{l(B, j)=1}^{K(B, j)} p_{k(B, j), l(B, j)}=1 .
$$

Let us select from all possible routes of wandering through the semi-Markov processes ${ }^{A} h(t)$ and ${ }^{B} h(t)$ routes as follows

$$
\begin{aligned}
& s_{l(A)}=[k(A, 1), \ldots, k(A, j), \ldots, k(A, J)], \\
& s_{l(B)}=[k(B, 1), \ldots, k(B, j), \ldots, k(B, J)] .
\end{aligned}
$$

The common number of selected routes is equal to

$$
K(A)=\prod_{j=1}^{J} K(A, j), \quad K(B)=\prod_{j=1}^{J} K(B, j) .
$$

The weighted time density of wandering from starting points of the distance ${ }^{A} a_{0},{ }^{B} a_{0}$ till end points of the distance ${ }^{A} a_{J}{ }^{B} a_{J}$ through the selected route is as follows [10-13]

$$
\begin{aligned}
& h_{k(A)}(t)=L^{-1}\left[\prod_{j=1}^{J} L\left[h_{k(A, j)}(t)\right]\right], \\
& h_{k(B)}(t)=L^{-1}\left[\prod_{j=1}^{J} L\left[h_{k(B, j)}(t)\right]\right]
\end{aligned}
$$

where $L[\ldots]$ and $L^{-1}[\ldots]$ are direct and inverse Laplace transforms, correspondingly. 
The probability of remaining the process on routes (9) may be estimated as follows:

$$
p_{k(A)}=\int_{0}^{\infty} h_{k(A)}(t) d t=\prod_{j=1}^{J} p_{k(A, j)}, \quad p_{k(B)}=\int_{0}^{\infty} h_{k(B)}(t) d t=\prod_{j=1}^{J} p_{k(B, j)} .
$$

The pure time density of wandering from states ${ }^{A} a_{0},{ }^{B} a_{0}$ till states ${ }^{A} a_{J},{ }^{B} a_{J}$ through the selected route is as follows $[14,15]$

$$
f_{k(A)}(t)=\frac{h_{k(A)}(t)}{p_{k(A)}}, \quad f_{k(B)}(t)=\frac{h_{k(B)}(t)}{p_{k(B)}} .
$$

The time density of wandering from the state ${ }^{m} a_{0}$ till the state ${ }^{m} a_{J}$ on any possible arbitrary route (13) is as follows

$$
{ }^{A} f_{\Sigma}(t)=\sum_{k(A)=1}^{K(A)} h_{k(A)}(t), \quad{ }^{B} f_{\Sigma}(t)=\sum_{k(B)=1}^{K(B)} h_{k(B)}(t)
$$

\section{Competition in Relay-Races}

Let us extract from all possible wandering routes of semi-Markov processes ${ }^{A} h(t)$ and ${ }^{B} h(t)$ routes (9), and numerate stages, in which participants situated at current time, as it is shown on the Fig. 1 . Then the second Cartesian degree of the set $\{1, \ldots, j, \ldots, J+1\}$ gives $S$ space of stages, in which teams $A$ and $B$ are situated in the current time during relay-race (Fig. 2). The race begins from state $(1,1)$ and ends at state $(J+1, J+1)$. Common number of states in the space $S$ is equal to $(J+1)^{2}$. Initial meaning of the vector is $[1,1]$. Wandering through the space has the character of evolution, in which after every switch one of the elements of vector increments by unit. At any switch incremental element is the only one. Switches continue till the vector reaches the state $[J+1, J+1]$ (teams are out of race). The common number of switches during evolution is as $2 J$.

The common quantity of switch trajectories grows fast in dependence of number of stages (R. Bellman's "curse of dimensionality" [16]). To define common quantity of switch trajectories let us find the $(2 J)$-th Cartesian degree of the set $\{A, B\}$ and gather all vectors, which include $J A$-s and $J B$-s into one set. Cardinality of this set is equal to $J$ -th binomial coefficient, i.e.

$$
Q_{2 J}^{J}=\frac{(2 J) !}{(J !)^{2}}
$$

During evolution route realizations $j(A)$ and $j(B)$ compete between them $[5,9]$. In common case, when two participants compete which start simultaneously and run their stages during the time, definable with densities $\theta_{A}(t)$ and $\theta_{B}(t)$, then time of completion the stage the first is as follows

$$
\theta_{w}(t)=\theta_{A}(t)\left[1-\Theta_{B}(t)\right]+\theta_{B}(t)\left[1-\Theta_{A}(t)\right]=\theta_{w A}(t)+\theta_{w B}(t),
$$

where $\theta_{w A}(t)$ is the weighted density of the time of winning the stage by participant $A$, $\theta_{w B}(t)$ is the weighted density of time of winning the stage by participant $\mathrm{A}, \Theta_{\ldots}(t)=$ $\int_{0}^{t} \theta_{\ldots}(\tau) d \tau$ is a distribution function.

Вестник ЮУрГУ. Серия «Математическое моделирование

и програм мирование» (Вестник ЮУрГУ ММП). 2018. Т. 11, № 1. С. 15-26 


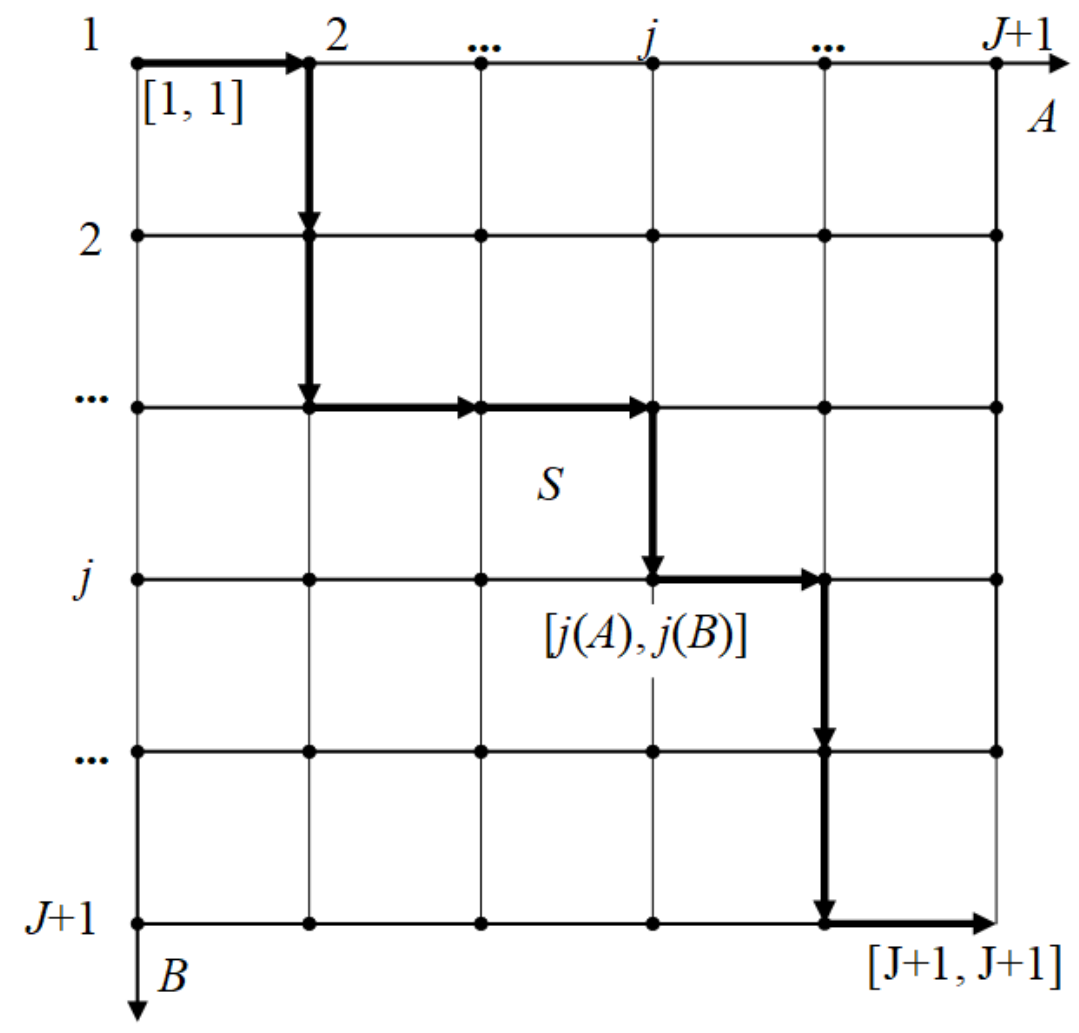

Fig. 2. Space $S$ of states (a) and the tree of switches (b)

The probabilities of the winning participants $A$ and $B$, and pure time densities of such events are as follows

$$
\begin{gathered}
\pi_{w A}=\int_{0}^{\infty} \theta_{w A}(t) d t, \quad \pi_{w B}=\int_{0}^{\infty} \theta_{w B}(t) d t, \\
\varphi_{w A}=\frac{\theta_{w A}(t)}{\pi_{w A}}, \quad \varphi_{w B}=\frac{\theta_{w B}(t)}{\pi_{w B}} .
\end{gathered}
$$

The second formula, necessary for relay-races simulation, is the dependence for the waiting time density. If in the competition wins the participant $B$, he waits until the participant completes his stage. The formula for density of waiting time is as follows $[3,5]$

$$
\theta_{B \rightarrow A}(t)=\frac{\eta(t) \int_{0}^{\infty} \theta_{B}(\xi) \theta_{A}(t+\xi) d \xi}{\int_{0}^{\infty} \Theta_{B}(t) d \Theta_{A}(t)}
$$

where $\eta(t)$ is the Heaviside function, $\xi$ is additional argument having the dimension of time, $\Theta_{A, B}(t)=\int_{0}^{t} \theta_{A, B}(\xi) d \xi$.

With the use of dependences (16) - (18) may be formed recursive procedure of relay-race evolution analysis. The recursive character of the evolution follows from the 
competitive character of choice of the next switch direction in space $S$. For building up the recursive procedure let us introduce auxiliary time density ${ }^{r} g_{j(A)}(t),{ }^{r} g_{j(A)}(t)$, where $r$ is the common number of switching during evolution, $j$ is the stage under consideration. Example of evolution is shown in Table.

Table

Evolution $m$-th and $n$-th swarms

\begin{tabular}{|l|l|l|}
\hline$r$ & $j(A), J(B)$ & Densities \\
\hline 0 & 1,1 & $f_{k(A, 1)}, f_{k(B, 1)},{ }^{0} g_{1(A)},{ }^{0} g_{1(B)}$ \\
\hline 1 & 1,2 & ${ }^{0} g_{1(B) \rightarrow 1(A)}, f_{k(B, 2)},{ }^{1} g_{1(A)},{ }^{1} g_{2(B)}$ \\
\hline 2 & 2,2 & $f_{k(A, 2)},{ }^{1} g_{1(A) \rightarrow 2(B)}$ \\
\hline & & $\ldots$ \\
\hline$r$ & $j(A), j(B)$ & $\ldots,{ }^{r} g_{j(A)},{ }^{r} g_{j(B)}$ \\
\hline$r+1$ & $j(A)+1, j(B)$ & $f_{k(A, j+1)},{ }^{1+1} g_{j(A) \rightarrow j(B)},{ }^{r+1} g_{j(A)+1},{ }^{r+1} g_{j(B)}$ \\
\hline & & $\ldots$ \\
\hline$R-2$ & $J(A), J(B)$ & $\ldots,{ }^{R-2} g_{J(A)},{ }^{R-2} g_{J(B)}$ \\
\hline$R-1$ & $J(A), J(B)+1$ & ${ }^{R-2} g_{J(B) \rightarrow J(A)},{ }^{R-1} g_{J(A)}$ \\
\hline$R$ & $J(A)+1, J(B)+1$ & Relay-race is over \\
\hline
\end{tabular}

On the first phase of recursion (no switches are made) original time densities $f_{k(A, 1)}, f_{k(B, 1)}$ compete with each of them. To formalize the competition description next substitution should be done

$$
{ }^{0} g_{1(A)}:=f_{k(A, 1)}, \quad{ }^{0} g_{1(B)}:=f_{k(B, 1)} .
$$

After winning the competition the participant from team $B$, as it is shown in the table, when $r=1$, time densities, which participates in the next phase are defined as follows

$$
\begin{gathered}
{ }^{1} g_{1(A)}:={ }^{0} g_{1(B)}(t) \rightarrow{ }^{0} g_{1(A)}(t)={ }^{0} g_{1(B) \rightarrow 1(A)}, \\
{ }^{1} g_{0(B)}:=f_{k(B, 2)},
\end{gathered}
$$

where ${ }^{0} g_{1(B)}(t) \rightarrow{ }^{0} g_{1(A)}(t)$ is the operation, defined as (18).

The probability of winning from the team $B$ participant is defined with formulae (17), which for the case under consideration is as follows

$$
\pi_{w 1(B)}=\int_{0}^{\infty}{ }^{0} g_{1(B)}(t)\left[1-{ }^{0} G_{1(A)}(t)\right] d t .
$$

After winning in the second switch the participant from team $A$, as it is shown in the table, when $r=2$, time densities, which participates in the next phase are defined as follows ${ }^{2} g_{2(A)}:=f_{k(A, 2)},{ }^{2} g_{2(B)}:={ }^{1} g_{1(A) \rightarrow 2(B)}$, etc.

Let us after $r$ switches in competition participate densities ${ }^{r} g_{j(A)}$ and ${ }^{r} g_{j(B)}$. If in this phase team A wins participant, then ${ }^{r+1} g_{j(A)+1}:=f_{k(A, j+1)}{ }^{r+2} g_{j(B)}:={ }^{r} g_{j(A) \rightarrow j(B)}$,

$$
\pi_{w j(A)}=\int_{0}^{\infty}{ }^{r} g_{j(A)}(t)\left[1-{ }^{r} G_{j(B)}(t)\right] d t, \text { etc. }
$$


In the $(R-2)$-th phase, when in competition of ${ }^{R-2} g_{J(A)}$ and ${ }^{R-2} g_{J(B) w i}$ team $B$, wins participant with probability

$$
\pi_{w j(B)}=\int_{0}^{\infty} R-2 g_{J(B)}(t)\left[1-{ }^{R-2} G_{J(A)}(t)\right] d t,
$$

team A participant stays at the distance alone, and ends $J$-th stage at the time ${ }^{R-2} g_{J(B) \rightarrow J(A)}$.

\section{Evaluation of Effectiveness of Alternative Relay-Race Strategy}

It is quite natural that for the evaluation of effectiveness one would use the model, in which team, which gets the stage with a higher number, acquires from the team, who gets the stage with a lower number, the forfeit, and forfeit is defined as distributed payment $c_{k(A, j), k(B, i)}(t)$, the value of which depends on the time, the difference of stages and selected routes. The analysis of the evolution shows that the situation, which changes the conditions of forfeit payments emerges from the winning of one of the participant (previous switch) and lasts till the next switch. If after $r$ switches densities ${ }^{r} g_{i(A)}(t)$ and ${ }^{r} g_{i(B)}(t)$ compete with each other, then the common sum of the forfeit at the stage is as follows $[3,5]$

$$
=\left\{\begin{array}{c}
{ }^{r} C_{k(A, j), k(B, i)}\left(q_{2 J}^{J}\right)= \\
\frac{\int_{0}^{\infty} r g_{j(A)}(t)\left[1-{ }^{r} G_{j(B)}(t)\right] c_{k(A, j), k(B, i)}(t) d t}{\int_{0}^{\infty} r g_{j(A)}(t)\left[1-{ }^{r} G_{j(B)}(t)\right] d t}, \text { when team } A \text { wins } \\
\frac{\int_{0}^{\infty} r g_{j(B)}(t)\left[1-{ }^{r} G_{i(A)}(t)\right] c_{k(B, i), k(A, j)}(t) d t}{\int_{0}^{\infty} r g_{j(B)}(t)\left[1-{ }^{r} G_{i(A)}(t)\right] d t}, \text { when team } B \text { wins }
\end{array}\right.
$$

where $q_{2 J}^{J}$ is the number of switching trajectory realization (common quantity of realizations $Q_{2 J}^{J}$ is defined with $\left.(15)\right)$.

The cost of the pair competition at the $q_{2 J}^{J}$-th switching trajectory is as follows

$$
C_{k(A, j), k(B, i)}\left(q_{2 J}^{J}\right)=\sum_{r=1}^{2 J}{ }^{r} C_{k(A, j), k(B, i)}\left(q_{2 J}^{J}\right) .
$$

The probability of emergence of $q$-th trajectory is as follows

$$
\pi_{k(A, j), k(B . i)}(q)=\prod_{r=1}^{2 J} \pi_{w}(r)
$$

where $\pi_{w}(r)$ is the probability of the proper direction choice at the switching trajectory, as it is shown in formulae $(21)-(23)$.

The common cost of the paired teams $A$ and $B$ relay-race at the pre-determined, $k(A)$-th and $k(B)$-th routes is as follows

$$
C_{k(A), k(B)}=\sum_{q_{2 J}^{J}=1}^{Q_{2 J}^{J}} \pi_{k(A, j), k(B . i)}\left(q_{2 J}^{J}\right) C_{k(m A j), k(B . i)}\left(q_{2 J}^{J}\right) .
$$


With the use (16) common cost of competition at the mentioned route pair is as follows

$$
C_{A, B}=\sum_{k(B)=1}^{K(B)} \sum_{k(A)=1}^{K(A)} p_{k(A)} p_{k(B)} C_{k(A), k(B)}
$$

Formula (28) may be used as a criterion of optimization of the behaviour of teams in relay race games. In this case the selection of possible routs, probabilities and time characteristics of the stage overcoming are alternative parameters. The methods of optimization task solving may be adopted from the game theory.

\section{Conclusion}

Working out the approach of modelling relay races with selectable routes opens a new page in the game theory because the competition develops in real physical time, and model of relay race practically reproduces real life situations. Moreover, at every stage, as in real life, there is a race between the participants of different teams, in which any participant can win or lose by time, that amplifies competitive moments of the game under consideration.

The further investigation in this area should be directed to finding more tight links with the classical game theory and use typical optimal strategies in the dynamic competitive condition $[17,18]$. Also it is possible to work out radically new strategies, oriented only on the use of the model of paired alternative route relay-races.

Acknowledgements. The research was carried out within the state assignment of the Ministry of Education and Science of Russian Federation (no. 2.3121.2017/PCH).

\section{References}

1. Heymann M. Concurrency and Discrete Event Control. IEEE Control Systems Magazine, 1990, vol. 10, pp. 103-112. DOI: 10.1109/37.56284

2. Chatterjee K., Jurdziński M., Henzinger T. Simple Stochastic Parity Games. Lecture Notes in Computer Science, 2003, vol. 2803, pp. 100-113. DOI: 10.1007/978-3-540-45220-1_11

3. Ivutin A.N, Larkin E.V. Simulation of Concurrent Games. Bulletin of the South Ural State University. Series: Mathematical Modelling, Programming and Computer Software, 2015, vol. 8 , no. 2, pp. $43-54$.

4. Valk R. Concurrency in Communicating Object Petri Nets. Concurrent Object-Oriented Programming and Petri Nets, 2001, pp. 164-195.

5. Larkin E.V., Ivutin A.N., Kotov V.V., Privalov A.N. Simulation of Relay-Races. Bulletin of the South Ural State University. Series: Mathematical Modelling, Programming and Computer Software, 2016, vol. 9, no. 4, pp. 117-128.

6. Larkin E.V., Ivutin A.N. Estimation of Latency in Embedded Real-Time Systems. 3-rd Meditteranean Conference on Embedded Computing (MECO-2014). Budva, Montenegro, 2014, pp. 236-239.

7. Korolyuk V., Swishchuk A. Semi-Markov Random Evolutions. N.Y., Springer-Science and Buseness Media, 1995. DOI: 10.1007/978-94-011-1010-5 
8. Iverson M.A., Ozguner F., Follen G.J. Run-Time Statistical Estimation of Task Execution Times for Heterogeneous Distributed Computing. Proceedings of 5th IEEE International Symposium on High Performance Distributed Computing, N.Y., USA, August 6-9, 1996. N.Y., Institute of Electrical and Electronics Engineers, 1996, pp. 263-270. DOI: 10.1109/HPDC.1996.546196

9. Limnios N., Swishchuk A. Discrete-Time Semi-Markov Random Evolutions and Their Applications. Advances in Applied Probability, 2013, vol. 45, no. 1, pp. 214-240. DOI: $10.1239 /$ aap $/ 1363354109$

10. Markov A.A. Extension of the Law of Large Numbers to Dependent Quantities. Izvestiya fiziko-matematicheskogo obshchestva pri Imperatorskom kazanskom universitete, 1906, vol. 15, pp. 135-156. (in Russian)

11. Bielecki T.R., Jakubowski J., Niewęgłowski M. Conditional Markov Chains: Properties, Construction and Structured Dependence. Stochastic Processes and Their Applications, 2017, vol. 127 , no. 4 , pp. 1125-1170. DOI: 10.1016/j.spa.2016.07.010

12. Janssen J., Manca R. Applied Semi-Markov Processes. N.Y., Springer, 2005.

13. Larkin E.V., Ivutin A.N., Kotov V.V., Privalov A.N. Semi-Markov Modeling of Command Execution by Mobile Robots. Interactive Collaborative Robotics (ICR 2016) Budapest, Hungary, Lecture Notes in Artifical Intelligence. Subseries of Lecture Notes in Computer Science. N.Y., Springer, 2016, pp. 189-198.

14. Bauer H. Probability Theory. Berlin, N.Y., Walter de Gruyter, 1996. DOI: $10.1515 / 9783110814668$

15. Shiryaev A.N. Probability. N.Y., Springer Science and Business Midia, 1996.

16. Bellman R.E. Dynamic Programming. N.Y., Dover Publications, 2003. DOI: 10.1007/978-1$4757-2539-1$

17. Myerson R.B. Game Theory. Cambridge, Harvard University Press, 1997.

18. Goetz B., Peierls T. Java Concurrency in Practice, Boston, Addison Wesley, 2006.

Received January 22, 2018

УДК 519.837

DOI: $10.14529 / \mathrm{mmp} 180102$

\title{
ЭСТАФЕТЫ ПО ВЫБРАННЫМ АЛЬТЕРНАТИВНЫМ МАРШРУТАМ
}

\author{
Е.В. Ларкин ${ }^{1}$, А.В. Богомолов ${ }^{2}$, А.Н. Привалов ${ }^{3}$, Н.Н. Доброволъский \\ ${ }^{1}$ Тульский государственный университет, г. Тула, Российская Федерация \\ ${ }^{2}$ Государственный научный центр Российской Федерации - Федеральный \\ медицинский биофизический центр им. А.И. Бурназяна, г. Москва, \\ Российская Федерация \\ ${ }^{3}$ Тульский государственный педагогический университет им. Л.Н. Толстого, \\ г. Тула, Российская Федерация
}

Рассматривается математическая модель, представляющая собой формализацию конкуренции двух команд, которые должны преодолевать дистанцию, состоящую из этапов. В рассматриваемом случае на каждом этапе есть различное количество маршрутов, которые участники команды могут выбрать для прохождения. Показано, что конкуренция носит характер эстафеты, а двухпараллельный полумарковский процесс - естественный подход к моделированию ситуации. 
Получена формула для расчета числа коммутационных траекторий. Показано, что из сложного двухпараллельного полумарковского процесса, описывающего блуждание по выбранным маршрутам, можно получить обычный полумарковский процесс с использованием рекурсивной процедуры. Предложены формулы для реализации рекурсии.

Предложена концепция распределенной неустойки. Показано, что неустойка зависит от разности этапов, команды преодолевают в текущее время и маршруты, по которым участники решали преодолеть этап. Получена формула оценки общей суммы неустойки, которую выплачивает одна команда другой команде. Показано, что сумма неустойки может использоваться в качестве критерия оптимизации в задаче оптимизации стратегии игры.

Ключевые слова: эстафета; двухпараллельный полумарковский процесс; дистанция; этап; маршрут; распределенная неустойка; рекурсивная процедура.

\section{Литература}

1. Heymann, M. Concurrency and Discrete Event Control / M. Heymann // IEEE Control Systems Magazine. - 1990. - V. 10. - P. 103-112.

2. Chatterjee, K. Simple Stochastic Parity Games / K. Chatterjee, M. Jurdziński, T. Henzinger // Lecture Notes in Computer Science. - 2003. - V. 2803. - P. 100-113.

3. Ivutin, A.N. Simulation of Concurrent Games / A.N. Ivutin, E.V. Larkin // Вестник ЮУрГУ. Серия: Математическое моделирование и программирование. -2015 . - Т. 8, № 2. C. $43-54$.

4. Valk, R. Concurrency in Communicating Object Petri Nets / R. Valk // Concurrent ObjectOriented Programming and Petri Nets. - 2001. - P. 164-195.

5. Larkin, E.V. Simulation of Relay-Races / E.V. Larkin, A.N. Ivutin, V.V. Kotov, A.N. Privalov // Вестник ЮУрГУ. Серия: Математическое моделирование и программирование. 2016. - Т. 9, № 4. - C. 117-128.

6. Larkin, E.V. Estimation of Latency in Embedded Real-Time Systems / E.V. Larkin, A.N. Ivutin // 3-rd Meditteranean Conference on Embedded Computing (MECO-2014). Budva; Montenegro, 2014. - P. 236-239.

7. Korolyuk, V. Semi-Markov Random Evolutions / V. Korolyuk, A. Swishchuk. - N.Y.: Springer-Science and Buseness Media, 1995.

8. Iverson, M.A. Run-Time Statistical Estimation of Task Execution Times for Heterogeneous Distributed Computing / M.A. Iverson, F. Ozguner, G.J. Follen // Proceedings of 5th IEEE International Symposium on High Performance Distributed Computing, N.Y., USA, August 6-9, 1996. - N.Y.: Institute of Electrical and Electronics Engineers, 1996. - P. 263-270.

9. Limnios, N. Discrete-Time Semi-Markov Random Evolutions and Their Applications N. Limnios, A. Swishchuk // Advances in Applied Probability. - 2013. - V. 45, № 1. P. 214-240.

10. Марков, А.А. Распространение закона больших чисел на величины, зависящие друг от друга / А.А. Марков // Известия физико-математического общества при Казанском университете. - 1906. - Т. 15. - С. 135-156.

11. Bielecki, T.R. Conditional Markov Chains: Properties, Construction and Structured Dependence / T.R. Bielecki, J. Jakubowski, M. Niewęgłowski // Stochastic Processes and Their Applications. - 2017. - V. 127, № 4. - P. 1125-1170.

12. Janssen, J. Applied Semi-Markov Processes / J. Janssen, R. Manca. - N.Y.: Springer, 2005. 
13. Larkin, E.V. Semi-Markov Modeling of Command Execution by Mobile Robots / E.V. Larkin, A.N. Ivutin, V.V. Kotov, A.N. Privalov // Interactive Collaborative Robotics (ICR 2016), Budapest, Hungary, Lecture Notes in Artifical Intelligence. Subseries of Lecture Notes in Computer Science. - N.Y.: Springer, 2016. - P. 189-198.

14. Bauer, H. Probability Theory / H. Bauer. - Berlin; N.Y.: Walter de Gruyter, 1996.

15. Shiryaev, A.N. Probability / A.N. Shiryaev. - N.Y.: Springer Science and Business Media, 1996.

16. Bellman, R.E. Dynamic Programming / R.E. Bellman. - N.Y.: Dover Publications, 2003.

17. Myerson, R.B. Game Theory / R.B. Myerson. - Cambridge: Harvard University Press, 1997.

18. Goetz, B. Java Concurrency in Practice / B. Goetz, T. Peierls. - Boston: Addison Wesley, 2006.

Евгений Васильевич Ларкин, доктор технических наук, профессор, кафедра «Робототехника и автоматизация производства», Тульский государственный университет (г. Тула, Российская Федерация), elarkin@mail.ru.

Алексей Валерьевич Богомолов, доктор технических наук, профессор, Государственный научный центр Российской Федерации - Федеральный медицинский биофизический центр им. А.И. Бурназяна (г. Москва, Российская Федерация), a.v.bogomolov@gmail.ru.

Александр Николаевич Привалов, доктор технических наук, профессор, кафедра «Информатика и информационные технологии», Тульский государственный педагогический университет им. Л.Н. Толстого (г. Тула, Российская Федерация), privalov.61@mail.ru.

Николай Николаевич Добровольский, кандидат физико-математических наук, доцент, Тульский государственный университет (г. Тула, Российская Федерация), nikolai.dobrovolsky@gmail.com.

Поступила в редакиию 22 января 2018 г. 